\title{
Imajinasi Kepemimpinan Politik Kita
}

\author{
Fathurozi \\ Staf Balai Penelitian dan Pengembangan Agama Semarang
}

Kepemimpinan adalah hal yang menarik banyak para pengkaji politik bila dikaitkan dengan Nabi Muhammad SAW. Tipe pemimpin yang dianggap ideal dalam ragam teori politik nampak dalam sosok pemimpin besar dari Jazirah Arab tersebut. Wajar bila akhirnya Michal $\mathrm{H}$. Hart menempatkan namanya pada nomor urut pertama dan utama tokoh paling berpengaruh dalam sejarah kepemimpinan umat manusia di dunia, hingga saat ini.

Kepemimpinan dalam diri Nabi menjelma sebagai anugerah dari langit. Baik sebagai pemimpin agama atau politik, pengaruh kebijakan dan kebijaksanaan beliau diharapkan oleh banyak orang, bahkan oleh orang yang tidak mengenalnya dan yang pernah bermusuhan. Ketika Hijrah ke Yastrib (Madinah), sambutan hangat atas kehadiran beliau sungguh tinggi. Dalam sambutan itu, Nabi diibaratkan sebagai purnama (al-badr). Orang menyambutnya dengan suka cita, bersyair dan bernyanyi: thala'al badru alaina/ telah datang purnama kepada kita.

Hingga saat ini, puisi pujian kepada Nabi oleh penduduk yang kemudian wilayahnya diberi nama oleh Nabi sebagai Madinah itu, tetap lestari. Fakta lain atas kerinduan banyak orang atas kepemimpinan Muhammad tersebar luas dalam kisah-kisah legenda nyata.

Cukuplah di sini saya katakan, rasa rindu akan kepemimpinan seseorang yang hendak mencalonkan diri sebagi tokoh nomor satu di daerah, misalnya, atau yang merasa mau menjadi wakil mereka untuk menyampaikan aspirasi, hampir sirna dalam tata sosio kehidupan politik kita.

Masyarakat hampir hilang imajinasinya tentang makna penting kepemimpinan. Justru ketika ada seseorang yang mencalonkan diri sebagai yang"merasa" berhak mengemban tugas kepemimpinan, tak ada yang mendukung kecuali dengan imbalanimbalan praktis yang menguntungkan. Rakyat kebanyakan beranggapan, pesta demokrasi bukan pesta yang perlu dirayakan sebagai ritual kehidupan penting, melainkan hanya sebagai ajang bagi-bagi kekuasaan yang menguntungkan kaum elite semata.

\section{Wakil Tuhan}

Sejatinya, kepemimpinan adalah suatu yang sakral dalam kehidupan politik. Tanpa pemimpin, dunia ibarat mata angin yang kita tidak mengetahui gerak arahnya akan kemana. Tradisi peradaban dari pelbagai belahan dunia memitoskan pemimpin sebagai perpanjangan kuasa Tuhan. Tradisi Jawa menyebut pemimpin sebagai ratu, wali, pengganti dewa dan sebagainya. Peradaan Islam klasik pun punya istilah sendiri menyebut pemegang kuasa politik sebagai khalifah dan atau imam. 
Yang pasti, seorang pemimpin diidentikkan sebagai orang yang dekat dengan penguasa alam semesta, Tuhan Yang Maha Kuasa. Karena itulah, para pemimpin atau dalam tradisi feodalisme Jawa Kuno disebut bangsawan adalah mereka yang mampu menjadi pembimbing jalan kebajikan dan kebijaksanaan masyarakat, yang baik mangkubumi (mengayomi alam semesta), pakubumi (mengendalikan dunia) karena lewat dialah, perubahan menuju keadaan hidup yang lebih baik dipegang kendali.

Demokrasi juga demikian. Tradisi kepemimpinan dalam demokrasi adalah "suara rakyat suara Tuhan". Walaupun legitimasi kekuasaan dalam politik demokrasi tersebut diserahkan kepada suara mayoritas, namun Tuhan tetap -seakan- dilibatkan secara legitimatif sebagai yang berhak atas segala kehendak kekuasaan. Gambaran di atas menunjukkan betapa skaralknya makna kepemimpinan dalam sekian produk kebudayan politik dari belahan dunia mana pun, melintas batas dan ruang.

Ironisnya, sakralitas kepemimpinan dalam dunia perpolitikan kita acapkali dinodai oleh faktor-faktor perebutan kekuasaan oleh mereka yang bersaing. Akibatnya, jalan meraih kekuasaan yang mengharuskan dirinya untuk melakukan "peperangan strategik" ptolitik sesaat atas nama ingin menjadi penguasa, telah menggeser falsafah kepemimpinan yang identik dengan dengan unsur kuasa Tuhan yang sakral itu.

\section{Liberalisasi Politik}

Demokrasi kebablasan yang terlanjur diterapkan sebagai sistem politik memilih calon pemimpin yang jujur, adil, merakyat dan bermartabat, sulit diwujudkan. Liberalisme politik demokrasi berhasil mencetak para penguasa begitu banyak, namun untuk mencetak pemimpin ideal, rasanya jauh dari harapan. Seagai gambaran sederhana saja, bila Anda ingin jadi orang nomor satu di suatu lembaga, institusi, atau di wilayah daerah tertentu, jejaring sosial saja tidak akan menjamin berhasil lolos tanpa dukungan kekuatan modal.

Akibatnya bisa ditebak, pemimpin hasil produk demokrasi liberal sekarang ini adalah mereka yang punya kekuatan modal dan jaringan modal lebih kuat. Intelektualitas, integritas, kredibilitas, moralitas, tidak banyak diperhitungkan dalam dunia kepemimpinan politik hingga saat ini. Wajar sajalah, kalau dalam setiap episode kepemimpinan, baik pusat, daerah atau interlokal, adalah episode kecemasan, kekhawatiran: jangan-jangan, kalau seumpama ada tokoh kesohor berhasil jadi pemimpin, dia akan melakukan korupsi, tidak progresif atau justru mengalami kemunduran di kemudian hari. Padahal, pemimpin merupakan arsitek masa depan.

Kekhawatiran-kekhawatiran yang menjulang itulah yang tidak memunculkan sambutan pujian seperti sambutan kedatangan Nabi di Madinah kala itu. Tidak ada nada optimisme thala'al badru, seperti disambutkan kepada Nabi Muhammad untuk sosok pemimpin produk demokrasi Indonesia saat ini. Suatu ketika, muncul harapan kepada sosok calon pemimpin yang punya tekad baik memperbaiki nasib masyarakat di daerahnya, tetapi pada akhir ia menjabat, malah menjadi terdakwa kasus suap atau korupsi. Kecewalah banyak orang. Agaknya mungkin benar bahwa presiden, guernur, bupati, camat, lurah, rektor, kepala sekolah, atau bahkan kepala rumah tangga sekalipun, bukalah seorang pemimpin, tapi hanya seorang pejabat. Kita adalah pemimpin bagi diri 